\title{
Parasutterella secunda sp. nov., isolated from human faeces and proposal of Sutterellaceae fam. nov. in the order Burkholderiales
}

\author{
Masami Morotomi, Fumiko Nagai and Yohei Watanabe \\ Yakult Central Institute for Microbiological Research, 1796 Yaho, Kunitachi, 186-8650 Tokyo, \\ Japan
}

Correspondence

Masami Morotomi

masami-morotomi@yakult.co.jp

\begin{abstract}
A novel, strictly anaerobic, non-spore-forming, Gram-reaction-negative coccobacillus bacterium, designated strain YIT $12071^{\top}$, was isolated from human faeces. Biochemically, this strain was largely unreactive and asaccharolytic. Growth of this strain in peptone-yeast-extract broth was weak, producing no visible turbidity, and no short-chain fatty acids were detected as an end product of metabolism. Following $16 \mathrm{~S}$ rRNA gene sequence analysis, strain YIT $12071^{\top}$ was found to be most closely related to Parasutterella excrementihominis ( $90 \%$ sequence similarity) and phylogenetically distinct from other known genera belonging to the order Burkholderiales. Biochemical data supported the affiliation of this strain with the genus Parasutterella. Strain YIT $12071^{\top}$, therefore, represents a novel species of the genus Parasutterella, for which the name Parasutterella secunda sp. nov. is proposed. The type strain is YIT $12071^{\top}$ (=DSM $22575^{\top}$ $\left.=J C M 16078^{\top}\right)$. On the basis of $16 \mathrm{~S}$ rRNA gene sequence analysis, species of the genera Sutterella and Parasutterella form a distinct and deep evolutionary lineage of descent in the order Burkholderiales. This lineage could not be associated with any of the four known families of the order Burkholderiales. The distinct phylogenetic position and the unusual combination of chemotaxonomic characteristics shared by these genera, such as the predominant quinones and cellular fatty acid compositions, suggest that they constitute a novel family in the order Burkholderiales, for which the name Sutterellaceae fam. nov. is proposed to accommodate the genera Sutterella and Parasutterella.
\end{abstract}

The human intestinal microbiota is a complex ecosystem containing hundreds of microbial species, a substantial proportion of which have not yet been cultured. Recent molecular ecological studies based on rRNA gene sequences have revealed that members of nine bacterial phyla were found to inhabit the human gastrointestinal tract, two of which, Firmicutes and Bacteroidetes, are dominant (see review Rajilić-Stojanović et al., 2007). The phylum Proteobacteria is usually secondary in numbers of bacteria present and members of the classes Alpha-, Beta-, Gamma-, Deltaand Epsilonproteobacteria have also been identified by using molecular techniques (Eckburg et al., 2005). Species of Proteobacteria such as Escherichia coli, Klebsiella pneumoniae and Enterobacter cloacae as well as some species of Proteus and Citrobacter have been identified, using conventional

Abbreviations: $\mathrm{APCl}$, atmospheric pressure chemical ionization; $\mathrm{ECL}$, equivalent chain-length; FAMEs, fatty acid methyl esters; ML, maximumlikelihood; MP, maximum-parsimony.

The GenBank/EMBL/DDBJ accession number for the 16S rRNA gene sequence of strain YIT $12071^{\top}$ is AB491209.

One supplementary table is available with the online version of this paper. culture techniques, as members of the human intestinal microbiota (Finegold et al., 1974; Holdeman et al., 1976; Moore \& Holdeman, 1974) and are all species belonging to the class Gammaproteobacteria. The species Sutterella wadsworthensis (Wexler et al., 1996; Engberg et al., 2000), Sutterella parvirubra (Sakon et al., 2008) and Parasutterella excrementihominis (Nagai et al., 2009) are also present but belong to the order Burkholderiales in the class Betaproteobacteria and were isolated during the course of several intensive cultivation trials aimed at isolating so-called 'unculturable' or 'as-yet-uncultured' bacteria from the human gastrointestinal tract (Sakon et al., 2008; Morotomi et al., 2008, 2009, 2010; Nagai et al., 2009, 2010a, b; Watanabe et al., 2010).

At the time of writing, the order Burkholderiales contains the families Burkholderiaceae, Oxalobacteraceae, Alcaligenaceae and Comamonadaceae (Garrity et al., 2005) and the genera Sutterella and Parasutterella have been placed in the family Alcaligenaceae (Busse \& Auling, 2005a; Wexler et al., 1996, 2005; Nagai et al., 2009; http://www.bacterio.cict.fr). In this study, a novel strain was isolated from human faeces, which represents a novel species of the genus Parasutterella. In addition, due to both the distinct phylogenetic positions and 
biological and biochemical differences of the genera Sutterella and Parasutterella from known genera in the family Alcaligenaceae, we propose that a novel family, with the name Sutterellaceae fam. nov., be instated to accommodate these two genera.

Faecal samples were collected from three healthy Japanese males (subjects $\mathrm{H}, \mathrm{O}$ and $\mathrm{K}$; aged 56, 38 and 28, respectively) and were immediately transferred to an anaerobic glove box (Coy Laboratory Products), containing $88 \%$ nitrogen, $7 \%$ hydrogen and $5 \%$ carbon dioxide, where each sample was weighed and diluted with pre-reduced $0.1 \mathrm{M}$ PBS ( $\mathrm{pH} 7$ ). Each dilution was then spread on modified Gifu anaerobic medium (GAM; Nissui Pharmaceutical) containing $1.5 \%(\mathrm{w} / \mathrm{v})$ agar that was supplemented with one of seven antibiotics, at three different concentrations, in an attempt to isolate subdominant groups of the intestinal microbiota. The composition of the modified GAM agar was described previously by Sakon et al. (2008). The inoculated plates were incubated at $37^{\circ} \mathrm{C}$ for 3 days in an anaerobic glove box. Strain YIT $12071^{\mathrm{T}}$ was isolated from GAM agar plates supplemented with oxacillin $\left(4 \mu \mathrm{g} \mathrm{ml}^{-1}\right.$; Sigma) and inoculated with a $10^{-6}$ serially diluted faecal sample from subject O. Single colonies were picked and streaked on the modified GAM agar until pure cultures were obtained. S. wadsworthensis DSM $14016^{\mathrm{T}}$ and Sutterella stercoricanis DSM $17807^{\mathrm{T}}$, purchased from the DSMZ, Germany, and P. excrementihominis YIT $11859^{\mathrm{T}}$ (Nagai et al., 2009) and Sutterella parvirubra YIT $11816^{\mathrm{T}}$ (Sakon et al., 2008), isolated previously from human faeces, were used as reference strains.

The end-products of bacterial metabolism in pre-reduced peptone-yeast extract (PY) medium (Holdeman et al., 1977) and PY medium supplemented with $1 \%$ glucose (PYG), lactate or succinate were analysed by HPLC as described previously (Chonan et al., 1995). Cell morphology was determined by examining 4-day-old modified GAM agar cultures using phase-contrast light microscopy. Biochemical characteristics were tested in duplicate using the API Rapid ID32A, API ZYM and API 20A systems (bioMérieux), according to the manufacturer's instructions. Oxidase activity was determined with Oxidase test strips (Eiken Chemical). Catalase activity was determined by the production of bubbles in a $3 \%$ hydrogen peroxide solution.

Cellular fatty acid methyl esters (FAMEs) were obtained from cells grown on modified GAM agar by saponification, methylation and extraction using the method of Miller (1982) with minor modifications (Kuykendall et al., 1988). FAMEs were determined by using the MIDI system with MOORE5 of the MIS Standard Libraries. Isoprenoid quinones were extracted as described by Komagata \& Suzuki (1987) and were analyzed by using an HPLCatmospheric pressure chemical ionization (APCI)-MS/MS system (API 3200, Applied Biosystems) with an L-column ODS $(2.1 \times 150 \mathrm{~mm}$, Chemicals Evaluation and Research
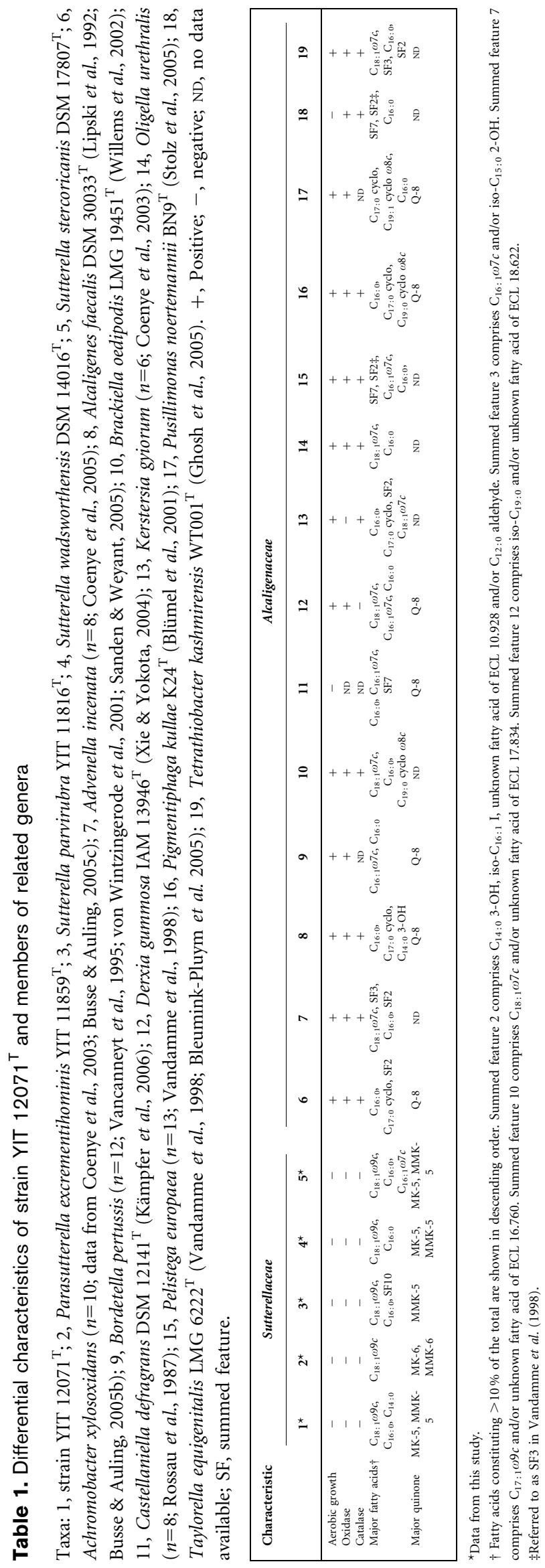
Institute), and an HPLC-APCI-MS system (Micromass ZQ equipped with 2996 photodiode array detector; Waters) with a Cadenza CD-C18 column $(3.0 \times 150 \mathrm{~mm}$; Imtakt), following the modified method of Katsuta et al. (2005). The DNA G+C content was determined by hydrolysing the DNA enzymically and quantifying the nucleosides by HPLC according to the method of Ezaki et al. (1990).

Closely related sequences were retrieved from the GenBank/EMBL/DDBJ by using the FASTA program (Lipman \& Pearson, 1985). Sequences were aligned and used to produce an unrooted phylogenetic tree according to the neighbour-joining method (Saitou \& Nei, 1987) using CLUSTAL_X (version 1.83) (Thompson et al., 1997). The stability of the groupings was estimated by bootstrap analysis (1000 replications). Trees were visualized by using the TreeView program (version 1.6.6) (Page, 1996). Maximum-parsimony (MP) and maximum-likelihood (ML) methods were used to confirm the phylogenetic placement of the aligned sequences. MP analysis was performed using the software package MEGA4 (Tamura et al., 2007). The ML tree was constructed via the PHYML program (Guindon \& Gascuel, 2003) using Kimura's two-parameter nucleotide substitution model (Kimura, 1980). The input file was prepared via the SEQBOOT program in the PHYLIP software package (Felsenstein, 2004).

Cells of strain YIT $12071^{\mathrm{T}}$ were Gram-reaction-negative, obligately anaerobic, non-motile coccobacilli, 0.4$1.3 \times 0.6-1.7 \mu \mathrm{m}$. After 4 days of anaerobic incubation at $37{ }^{\circ} \mathrm{C}$ on modified GAM agar, colonies were translucent to beige, circular, convex and pinpoint in size. Growth of strain YIT $12071^{\mathrm{T}}$ in PY broth was weak, producing no visible turbidity, and no short-chain fatty acids were detected as an end product of metabolism. Addition of glucose, lactate or succinate did not enhance growth or the production of short-chain fatty acids. The strain was asaccharolytic in API test systems. Tests for indole production, nitrate reduction, catalase and urease activities and aesculin and gelatin hydrolysis were negative. In the API Rapid ID 32A and API ZYM test systems, strain YIT $12071^{\mathrm{T}}$ was largely unreactive but was positive for arginine dihydrolase, esterase (C4), esterase lipase (C8) and naphthol-AS-BI-phosphohydrolase activities. Alkaline phosphatase activity was positive in the API Rapid ID $32 \mathrm{~A}$ system and weakly positive in the API ZYM test system. All other test results were negative. Other

Table 2. Fatty acid compositions of strain YIT $12071^{\top}$ and type strains of the genera Parasutterella and Sutterella

Taxa: 1, strain YIT $12071^{\mathrm{T}} ; 2$, Parasutterella excrementihominis YIT $11859^{\mathrm{T}} ; 3$, Sutterella parvirubra YIT $11816^{\mathrm{T}}$; 4, Sutterella wadsworthensis DSM $14016^{\mathrm{T}} ; 5$, Sutterella stercoricanis DSM $17807^{\mathrm{T}}$. Values are percentages of total fatty acids; only those fatty acids that make up $>1 \%$ of the total are shown. Data were obtained in this study.

\begin{tabular}{|c|c|c|c|c|c|}
\hline Fatty acid & 1 & 2 & 3 & 4 & 5 \\
\hline \multicolumn{6}{|c|}{ Saturated straight-chain } \\
\hline $\mathrm{C}_{12: 0}$ & 2.82 & & & & \\
\hline $\mathrm{C}_{15: 0}$ & & & 1.36 & 1.01 & 1.10 \\
\hline $\mathrm{C}_{16: 0}$ & 14.09 & 8.66 & 21.13 & 15.68 & 23.19 \\
\hline $\mathrm{C}_{18: 0}$ & 2.82 & 1.46 & 3.25 & 1.04 & 1.38 \\
\hline $\mathrm{C}_{16: 1} \omega 7 c$ & 1.29 & & 6.13 & 1.69 & 23.10 \\
\hline $\mathrm{C}_{18: 2} \omega 6,9 c$ & & & 1.27 & & \\
\hline $\mathrm{C}_{18: 1} \omega 9 c$ & 39.95 & 68.10 & 43.36 & 56.37 & 31.77 \\
\hline \multicolumn{6}{|l|}{ Hydroxy acids } \\
\hline $\mathrm{C}_{16: 0} 3-\mathrm{OH}$ & & 6.26 & & & \\
\hline \multicolumn{6}{|c|}{ Dimethyl acetal (DMA) } \\
\hline 2 & 4.17 & & 2.43 & 2.07 & 2.81 \\
\hline 5 & 3.68 & & 2.19 & 3.79 & 1.86 \\
\hline 7 & 1.05 & & & & \\
\hline 10 & 6.60 & 4.43 & 12.98 & 5.06 & 7.78 \\
\hline 12 & 2.57 & & & 1.11 & \\
\hline
\end{tabular}

${ }^{\star}$ Summed feature composition is as follows: $1, \mathrm{C}_{13: 1} \omega 12 c$ and/or $\mathrm{C}_{14: 0}$ aldehyde; $2, \mathrm{C}_{12: 0}$ 3-OH and/or $\mathrm{C}_{13: 0}$ DMA; 5, $\mathrm{C}_{15: 0}$ DMA and/or $\mathrm{C}_{14: 0}$ $3-\mathrm{OH} ; 7, \mathrm{C}_{17: 1} \omega 9 c$ and/or unknown fatty acid of ECL 16.760; 10, $\mathrm{C}_{18: 1} \omega 7 c$ and/or unknown fatty acid of ECL 17.834; 12 , iso-C $19: 0$ and/or unknown fatty acid of ECL 18.622. 
biochemical characteristics obtained by using the API Rapid ID32A and API ZYM test systems are included in the species description. The biological and biochemical characteristics that differentiate species of the genera Parasutterella and Sutterella from type species of genera in the family Alcaligenaceae are summarized in Table 1.

All strains of the genera Parasutterella and Sutterella tested were oxidase- and catalase-negative and no aerobic growth was observed. The opposite was found for type species of genera in the family Alcaligenaceae (Table 1).

Cellular fatty acid and isoprenoid quinone profiles of strain YIT $12071^{\mathrm{T}}$ and type strains of species of the genera Parasutterella and Sutterella are provided in Table 2 and Supplementary Table S1, respectively. All of these strains contained $\mathrm{C}_{18: 1} \omega 9 c(32-68 \%)$ and $\mathrm{C}_{16: 0}(9-23 \%)$ as the predominant fatty acids. Some minor qualitative and quantitative differences in fatty acid content could be observed but the overall patterns were very similar among species of these genera. The fatty acid $\mathrm{C}_{18: 1} \omega 9 \mathrm{c}$, on the other hand, has not been reported to be a major component in species of the family Alcaligenaceae (Table 1). The major respiratory quinone of strain YIT $12071^{\mathrm{T}}$ was methylmenaquinone-5 (MMK-5; $91 \%$ ). Menaquinone-5 (MK-5; 9\%) was also detected (Supplementary Table S1). The major respiratory quinone of the other type strains of the genera Parasutterella and Sutterella was also MMK-5 except for $P$. excrementihominis YIT $11589^{\mathrm{T}}$, in which MMK-6 was dominant (Supplementary Table S1). The typical fragmentation of a ubiquinone ring nucleus at mole peak $\mathrm{m} / \mathrm{z} 197$ was not detected in all these strains, indicating ubiquinones are not present in strains of the genera Parasutterella and Sutterella. Contrary to this, species of the family Alcaligenaceae have, in general, been characterized by the presence of ubiquinone- $8(\mathrm{Q}-8)$ as the major isoprenoid quinone (Table 1; Fletcher et al., 1987; Oyaizu-Masuchi \& Komagata, 1988).

A 1485 bp region of the $16 \mathrm{~S}$ rRNA gene of strain YIT $12071^{\mathrm{T}}$ was sequenced. Database searches revealed a high similarity between strain YIT $12071^{\mathrm{T}}$ and $P$. excrementihominis $(90.0 \%)$. Phylogenetic analyses of these and other related sequences were performed and confirmed that strain YIT $12071^{\mathrm{T}}$ was phylogenetically most closely associated with, but formed a separate cluster from, $P$. excrementihominis YIT $11859^{\mathrm{T}}$ (Fig. 1). Despite this close association, the 16S rRNA gene sequence of strain YIT $12071^{\mathrm{T}}$ shared highest sequence similarities (98.6-99.4\%) with uncultured intestinal bacteria derived from studies of swine, cows and turkeys [GenBank accession nos: AF371864 (Leser et al., 2002); DQ455891 (Scupham, 2007); EU009773 (Scupham et al., 2008); EU794169 (Patton et al., 2009)] (Fig. 1). In all phylogenetic trees, strain YIT $12071^{\mathrm{T}}$, together with the recently observed uncultured clone sequences, formed a distinct monophyletic clade ( $99.9 \%$ bootstrap support) within the order Burkholderiales (Fig. 1). This lineage could not be associated with any of the four known families in the order Burkholderiales. The DNA G $+\mathrm{C}$ content of strain YIT $12071^{\mathrm{T}}$ was $48.2 \mathrm{~mol} \%$, similar to that of P. excrementihominis $(49.8 \%)$.

Based on the phylogenetic, phenotypic and chemotaxonomic evidence, strain YIT $12071^{\mathrm{T}}$ represents a novel species of the genus Parasutterella, for which the name Parasutterella secunda sp. nov. is proposed.

At the time of writing, the order Burkholderiales contains four families, Burkholderiaceae, Oxalobacteraceae, Alcaligenaceae and Comamonadaceae (Garrity et al., 2005). Based on the distinct phylogenetic position of the genera Sutterella and

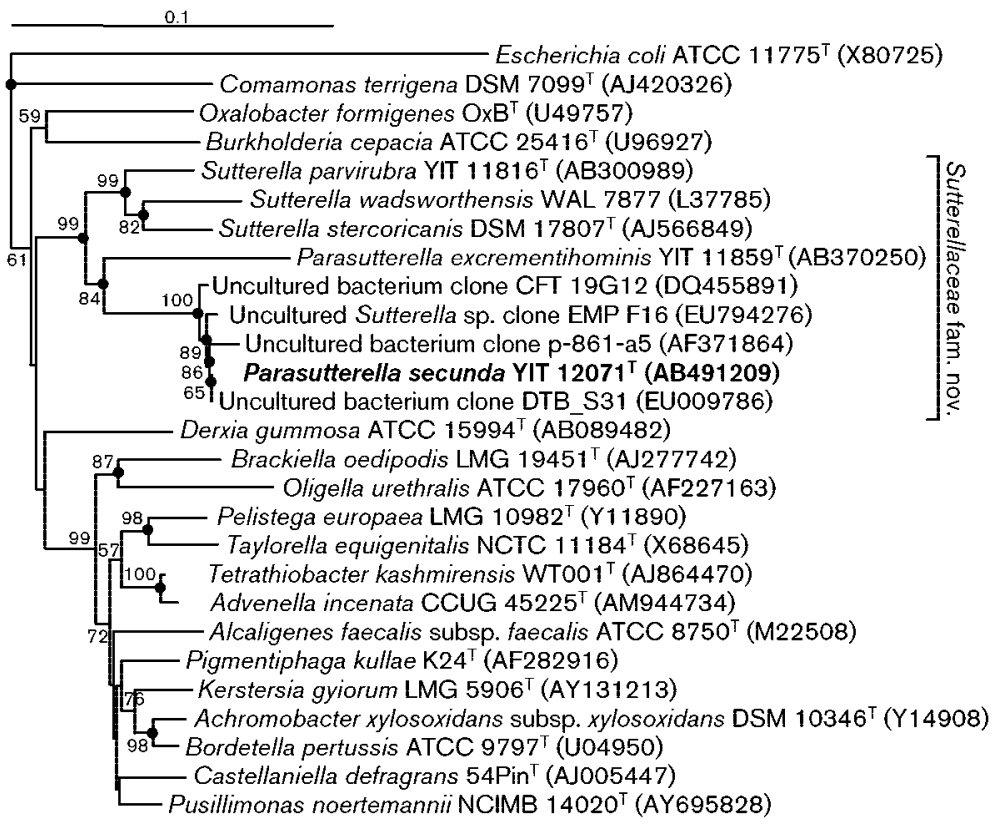

Fig. 1. Phylogenetic tree showing the relationships between strain YIT $12071^{\top}$, strains representing genera of the family Alcaligenaceae and related taxa in the order Burkholderiales based on 16S rRNA gene sequence analysis. The tree was rooted with Escherichia coli ATCC $11775^{\top}$ as an outgroup and was constructed by using the neighbour-joining method based on the comparison of sequences of $\sim 1300 \mathrm{nt}$. Bootstrap values $>50 \%$ (based on 1000 replications) are given at branch points. Similar tree topologies were obtained by using the MP and $\mathrm{ML}$ methods (data not shown). Filled circles indicate that the corresponding nodes were also recovered in trees generated with the MP and ML methods. GenBank accession numbers are shown in parentheses. Bar, 0.1 substitutions per nucleotide position. 
Parasutterella within the order Burkholderiales and the differences observed in the biological and chemotaxonomic characterization, it is proposed that a novel family, Sutterellaceae fam. nov., should be created to accommodate these genera.

\section{Description of Sutterellaceae fam. nov.}

Sutterellaceae (Sut.te.rel.la'ce.ae. N.L. fem. n. Sutterella type genus of the family; -aceae ending to denote a family; N.L. fem. pl. n. Sutterellaceae the Sutterella family).

Cells are Gram-reaction-negative rods or coccobacilli and grow under anaerobic conditions or in a microaerophilic atmosphere. Negative for oxidase and catalase activities. The main isoprenoid quinone is MMK-5 or MMK-6. Phylogenetically, the family is a member of the class Betaproteobacteria of the order Burkholderiales. The type genus is Sutterella Wexler et al. 1996.

\section{Description of Parasutterella secunda sp. nov.}

Parasutterella secunda (se.cun' da. L. fem. adj. secunda next to the first, the second, referring to the second species of the genus Parasutterella to be described).

Cells are Gram-reaction-negative, non-motile, strictly anaerobic, asaccharolytic, non-spore-forming cocci to coccobacilli, $0.4-1.3 \times 0.6-1.7 \mu \mathrm{m}$. Colonies are translucent to beige, circular, convex and pinpoint in size after 4 days of growth at $37^{\circ} \mathrm{C}$ on modified GAM agar under anaerobic conditions. Negative for nitrate reduction, indole production, catalase, urease and oxidase activities and aesculin and gelatin hydrolysis. In the API test systems, tests are positive for alkaline phosphatase (weakly positive in the API ZYM system), arginine dihydrolase, esterase (C4), esterase lipase (C8) and naphthol-AS-BI-phosphohydrolase activities. Negative for $N$-acetyl- $\beta$-glucosaminidase, acid phosphatase, alanine arylamidase, $\alpha$-arabinosidase, arginine arylamidase, chymotrypsin, cystine arylamidase, $\alpha$-fucosidase, $\alpha$ - and $\beta$-galactosidase, 6 -phosphate- $\beta$-galactosidase, $\alpha$ - and $\beta$-glucosidase, $\beta$-glucuronidase, glutamic acid decarboxylase, glutamyl glutamic acid arylamidase, glycine arylamidase, histidine arylamidase, leucine arylamidase, leucyl glycine arylamidase, lipase (C14), $\alpha$-mannosidase, phenylalanine arylamidase, proline arylamidase, pyroglutamic acid arylamidase, serine arylamidase, trypsin, tyrosine arylamidase and valine arylamidase activities. The major cellular fatty acids are $\mathrm{C}_{18: 1} \omega 9 c, \mathrm{C}_{16: 0}$ and $\mathrm{C}_{14: 0}$. The major respiratory quinone is MMK- $5\left(\mathrm{H}_{0}\right)$.

The type strain, YIT $12071^{\mathrm{T}}\left(=\mathrm{DSM} 22575^{\mathrm{T}}=\mathrm{JCM}\right.$ $\left.16078^{\mathrm{T}}\right)$, was isolated from human faeces. The DNA $\mathrm{G}+\mathrm{C}$ content of the type strain is $48.2 \mathrm{~mol} \%$.

\section{Acknowledgements}

We are grateful to Dr Jean Euzéby of the École Nationale Vétérinaire in Toulouse for his suggestions regarding the etymology of the species epithet. We thank K. Harada, H. Sakon and K. Manabe for their advice and help with the quinone analysis. We also thank Dr Ryuichiro Tanaka and Dr Haruji Sawada for their understanding and encouragement throughout our research activities.

\section{References}

Bleumink-Pluym, N. M. C. \& van der Zeijst, B. A. M. (2005). Genus IX. Taylorella Sugimoto, Isayama, Sakazaki and Kuramochi $1984,503^{\mathrm{VP}}$ (Effective publication: Sugimoto, Isayama, Sakazaki and Kuramochi 1983, 155). In Bergy's Manual of Systematic Bacteriology, 2nd edn, vol. 2, The Proteobacteria, part C, The Alpha-, Beta-, Deltaand Epsilonproteobacteria, pp. 684-685. Edited by D. J. Brenner, N. P. Kreig, J. T. Staley \& G. M. Garrity. New York: Springer.

Blümel, S., Mark, B., Busse, H.-J., Kämpfer, P. \& Stolz, A. (2001). Pigmentiphaga kullae gen. nov., sp. nov., a novel member of the family Alcaligenaceae with the ability to decolorize azo dyes aerobically. Int $J$ Syst Evol Microbiol 51, 1867-1871.

Busse, H. \& Auling, G. (2005a). Family Alcaligenaceae De Ley, Segers, Kersters, Mannheim and Lievens 1986, 412 VP. In Bergey's Manual of Systematic Bacteriology, 2nd edn, vol. 2, The Proteobacteria, part C, The Alpha-, Beta-, Delta- and Epsilonproteobacteria, pp. 647-653. Edited by D. J. Brenner, N. P. Kreig, J. T. Staley \& G. M. Garrity. New York: Springer.

Busse, H. J. \& Auling, G. (2005b). Genus Alcaligenes Castellani and Chalmers 1919, 936 ${ }^{\mathrm{AL}}$. In Bergey's Manual of Systematic Bacteriology, 2nd edn, vol. 2, The Proteobacteria, part C, The Alpha-, Beta-, Deltaand Epsilonproteobacteria, pp. 653-658. Edited by D. J. Brenner, N. P. Kreig, J. T. Staley \& G. M. Garrity. New York: Springer.

Busse, H. \& Auling, G. (2005c). Genus Achromobacter Yabuuchi and Yano 1981, 477 VP. In Bergey's Manual of Systematic Bacteriology, 2nd edn, vol. 2, The Proteobacteria, part C, The Alpha-, Beta-, Delta-, and Epsilonproteobacteria, pp. 658-662. Edited by D. J. Brenner, N. P. Kreig, J. T. Staley \& G. M. Garrity. New York: Springer.

Chonan, O., Matsumoto, K. \& Watanuki, M. (1995). Effect of galactooligosaccharides on calcium absorption and preventing bone loss in ovariectomized rats. Biosci Biotechnol Biochem 59, 236-239.

Coenye, T., Vancanneyt, M., Cnockaert, M. C., Falsen, E., Swings, J. \& Vandamme, P. (2003). Kerstersia gyiorum gen. nov., sp. nov., a novel Alcaligenes faecalis-like organism isolated from human clinical samples, and reclassification of Alcaligenes denitrificans Rüger and Tan 1983 as Achromobacter denitrificans comb. nov. Int J Syst Evol Microbiol 53, 1825-1831.

Coenye, T., Vanlaere, E., Samyn, E., Falsen, E., Larsson, P. \& Vandamme, P. (2005). Advenella incenata gen. nov., sp. nov., a novel member of the Alcaligenaceae, isolated from various clinical samples. Int J Syst Evol Microbiol 55, 251-256.

Eckburg, P. B., Bik, E. M., Bernstein, C. N., Purdom, E., Dethlefsen, L., Sargent, M., Gill, S. R., Nelson, K. E. \& Relman, D. A. (2005). Diversity of the human intestinal microbial flora. Science 308, 16351638.

Engberg, J., On, S. L., Harrington, C. S. \& Gerner-Smidt, P. (2000). Prevalence of Campylobacter, Arcobacter, Helicobacter, and Sutterella spp. in human fecal samples as estimated by a reevaluation of isolation methods for Campylobacters. J Clin Microbiol 38, 286291.

Ezaki, T., Saidi, S. M., Liu, S. L., Hashimoto, Y., Yamamoto, H. \& Yabuuchi, E. (1990). Rapid procedure to determine the DNA base composition from small amounts of gram-positive bacteria. FEMS Microbiol Lett 67, 127-130.

Felsenstein, J. (2004). PHYLIP (phylogeny inference package), version 3.6. Distributed by the author. Department of Genome Sciences, University of Washington, Seattle, USA. 
Finegold, S. M., Attebery, H. R. \& Sutter, V. L. (1974). Effect of diet on human fecal flora: comparison of Japanese and American diets. Am J Clin Nutr 27, 1456-1469.

Fletcher, M. T., Blackall, P. J. \& Doheny, C. M. (1987). A note on the isoprenoid quinone content of Bordetella avium and related species. J Appl Bacteriol 62, 275-277.

Garrity, G. M., Bell, J. A. \& Lilburn, T. (2005). Order I. Burkholderiales ord. nov. In Bergey's Manual of Systematic Bacteriology, 2nd edn, vol. 2, The Proteobacteria, part C, The Alpha-, Beta-, Delta- and Epsilonproteobacteria, p. 575. Edited by D. J. Brenner, N. R. Krieg, J. T. Staley \& G. M. Garrity. New York: Springer.

Ghosh, W., Bagchi, A., Mandal, S., Dam, B. \& Roy, P. (2005). Tetrathiobacter kashmirensis gen. nov., sp. nov., a novel mesophilic, neutrophilic, tetrathionate-oxidizing, facultatively chemolithotrophic betaproteobacterium isolated from soil from a temperate orchard in Jammu and Kashmir, India. Int J Syst Evol Microbiol 55, 1779-1787.

Guindon, S. \& Gascuel, O. (2003). A simple, fast, and accurate algorithm to estimate large phylogenies by maximum likelihood. Syst Biol 52, 696-704.

Holdeman, L. V., Good, I. J. \& Moore, W. E. (1976). Human fecal flora: variation in bacterial composition within individuals and a possible effect of emotional stress. Appl Environ Microbiol 31, 359-375.

Holdeman, L. V., Cato, E. P. \& Moore, W. E. C. (1977). Anaerobe Laboratory Manual, 4th edn. Blacksburg, VA: Virginia Polytechnic Institute and State University.

Kämpfer, P., Denger, K., Cook, A. M., Lee, S.-T., Jäckel, U., Denner, E. B. M. \& Busse, H.-J. (2006). Castellaniella gen. nov., to accommodate the phylogenetic lineage of Alcaligenes defragrans, and proposal of Castellaniella defragrans gen. nov., comb. nov. and Castellaniella denitrificans sp. nov. Int J Syst Evol Microbiol 56, 815819.

Katsuta, A., Adachi, K., Matsuda, S., Shizuri, Y. \& Kasai, H. (2005). Ferrimonas marina sp. nov. Int J Syst Evol Microbiol 55, 1851-1855.

Kimura, M. (1980). A simple method for estimating evolutionary rates of base substitutions through comparative studies of nucleotide sequences. J Mol Evol 16, 111-120.

Komagata, K. \& Suzuki, K. (1987). Lipid and cell-wall analysis in bacterial systematics. Methods Microbiol 19, 161-207.

Kuykendall, L. D., Roy, M. A., O'Neill, J. J. \& Devine, T. E. (1988). Fatty acids, antibiotic resistance, and deoxyribonucleic acid homology groups of Bradyrhizobium japonicum. Int J Syst Bacteriol 38, 358-361.

Leser, T. D., Amenuvor, J. Z., Jensen, T. K., Lindecrona, R. H., Boye, M. \& Møller, K. (2002). Culture-independent analysis of gut bacteria: the pig gastrointestinal tract microbiota revisited. Appl Environ Microbiol 68, 673-690.

Lipman, D. J. \& Pearson, W. R. (1985). Rapid and sensitive protein similarity searches. Science 227, 1435-1441.

Lipski, A., Klatte, S., Bendinger, B. \& Altendorf, K. (1992). Differentiation of Gram-negative, nonfermentative bacteria isolated from biofilters on the basis of fatty acid composition, quinone system, and physiological reaction profiles. Appl Environ Microbiol 58, 20532065.

Miller, L. T. (1982). Single derivatization method for routine analysis of bacterial whole-cell fatty acid methyl esters, including hydroxy acids. J Clin Microbiol 16, 584-586.

Moore, W. E. \& Holdeman, L. V. (1974). Human fecal flora: the normal flora of 20 Japanese-Hawaiians. Appl Microbiol 27, 961-979.

Morotomi, M., Nagai, F., Sakon, H. \& Tanaka, R. (2008). Dialister succinatiphilus sp. nov. and Barnesiella intestinihominis sp. nov., isolated from human faeces. Int J Syst Evol Microbiol 58, 27162720.
Morotomi, M., Nagai, F., Sakon, H. \& Tanaka, R. (2009). Paraprevotella clara gen. nov., sp. nov. and Paraprevotella xylaniphila sp. nov., members of the family 'Prevotellaceae' isolated from human faeces. Int J Syst Evol Microbiol 59, 1895-1900.

Morotomi, M., Nagai, F., Watanabe, Y. \& Tanaka, R. (2010). Succinatimonas hippei gen. nov., sp. nov., isolated from human faeces. Int J Syst Evol Microbiol 60, 1788-1793.

Nagai, F., Morotomi, M., Sakon, H. \& Tanaka, R. (2009). Parasutterella excrementihominis gen. nov., sp. nov., a member of the family Alcaligenaceae isolated from human faeces. Int J Syst Evol Microbiol 59, 1793-1797.

Nagai, F., Morotomi, M., Watanabe, Y., Sakon, H. \& Tanaka, R. (2010a). Alistipes indistinctus sp. nov. and Odoribacter laneus sp. nov., common members of the human intestinal microbiota isolated from faeces. Int J Syst Evol Microbiol 60, 1296-1302.

Nagai, F., Watanabe, Y. \& Morotomi, M. (2010b). Slackia piriformis sp. nov. and Collinsella tanakaei sp. nov., new members of the family Coriobacteriaceae, isolated from human faeces. Int J Syst Evol Microbiol 60, 2639-2646.

Oyaizu-Masuchi, Y. \& Komagata, K. (1988). Isolation of free-living nitrogen-fixing bacteria from the rhizosphere of rice. J Gen Appl Microbiol 34, 127-164.

Page, R. D. M. (1996). TREEviEW: an application to display phylogenetic trees on personal computers. Comput Appl Biosci 12, 357-358.

Patton, T. G., Scupham, A. J., Bearson, S. M. \& Carlson, S. A. (2009). Characterization of fecal microbiota from a Salmonella endemic cattle herd as determined by oligonucleotide fingerprinting of rDNA genes. Vet Microbiol 136, 285-292.

Rajilić-Stojanović, M., Smidt, H. \& de Vos, W. M. (2007). Diversity of the human gastrointestinal tract microbiota revisited. Environ Microbiol 9, 2125-2136.

Rossau, R., Kersters, K., Falsen, E., Jantzen, E., Segers, P., Union, A., Nehls, L. \& De Ley, J. (1987). Oligella, a new genus including Oligella urethralis comb. nov. (formerly Moraxella urethralis), and Oligella ureolytica sp. nov. (formerly CDC group IVe): relationship to Taylorella equigenitalis and related taxa. Int J Syst Bacteriol 37, 198210.

Saitou, N. \& Nei, M. (1987). The neighbor-joining method: a new method for reconstructing phylogenetic trees. Mol Biol Evol 4, 406-425.

Sakon, H., Nagai, F., Morotomi, M. \& Tanaka, R. (2008). Sutterella parvirubra sp. nov. and Megamonas funiformis sp. nov., isolated from human faeces. Int J Syst Evol Microbiol 58, 970-975.

Sanden, G. N. \& Weyant, R. S. (2005). Genus Bordetella MorenoLópez 1952, 178 ${ }^{\mathrm{AL}}$. In Bergey's Manual of Systematic Bacteriology, 2nd edn, vol. 2, The Proteobacteria, part C, The Alpha-, Beta-, Delta- and Epsilonproteobacteria, pp. 662-671. Edited by D. J. Brenner, N. P. Kreig, J. T. Staley \& G. M. Garrity. New York: Springer.

Scupham, A. J. (2007). Succession in the intestinal microbiota of preadolescent turkeys. FEMS Microbiol Ecol 60, 136-147.

Scupham, A. J., Patton, T. G., Bent, E. \& Bayles, D. O. (2008). Comparison of the cecal microbiota of domestic and wild turkeys. Microb Ecol 56, 322-331.

Stolz, A., Bürger, S., Kuhm, A., Kämpfer, P. \& Busse, H.-J. (2005). Pusillimonas noertemannii gen. nov., sp. nov., a new member of the family Alcaligenaceae that degrades substituted salicylates. Int J Syst Evol Microbiol 55, 1077-1081.

Tamura, K., Dudley, J., Nei, M. \& Kumar, S. (2007). MEGA4: molecular evolutionary genetic analysis (MEGA) software version 4.0. Mol Biol Evol 24, 1596-1599.

Thompson, J. D., Gibson, T. J., Plewniak, F., Jeanmougin, F. \& Higgins, D. G. (1997). The CLUSTAL_X windows interface: 
flexible strategies for multiple sequence alignment aided by quality analysis tools. Nucleic Acids Res 25, 4876-4882.

Vancanneyt, M., Vandamme, P. \& Kersters, K. (1995). Differentiation of Bordetella pertussis, B. parapertussis, and $B$. bronchiseptica by whole-cell protein electrophoresis and fatty acid analysis. Int J Syst Bacteriol 45, 843-847.

Vandamme, P., Segers, P., Ryll, M., Hommez, J., Vancanneyt, M., Coopman, R., De Baere, R., Van de Peer, Y., Kersters, K. \& other authors (1998). Pelistega europaea gen. nov., sp. nov., a bacterium associated with respiratory disease in pigeons: taxonomic structure and phylogenetic allocation. Int J Syst Bacteriol 48, 431-440.

von Wintzingerode, F., Schattke, A., Siddiqui, R. A., Rösick, U., Göbel, U. B. \& Gross, R. (2001). Bordetella petrii sp. nov., isolated from an anaerobic bioreactor, and emended description of the genus Bordetella. Int J Syst Evol Microbiol 51, 1257-1265.

Watanabe, Y., Nagai, F., Morotomi, M., Sakon, H. \& Tanaka, R. (2010). Bacteroides clarus sp. nov., Bacteroides fluxus sp. nov. and Bacteroides oleiciplenus sp. nov., isolated from human faeces. Int J Syst Evol Microbiol 60, 1864-1869.
Wexler, H. M. (2005). Genus VIII. Sutterella Wexler, Reeves, Summanen, Molitoris, McTeague, Duncan, Wilson and Finegold 1996a $257^{\mathrm{VP}}$. In Bergey's Manual of Systematic Bacteriology, 2nd edn, vol. 2, The Proteobacteria, part C, The Alpha-, Beta-, Delta- and Epsilonproteobacteria, 2nd edn, vol. 2, pp. 682-684. Edited by D. J. Brenner, N. R. Kreig, J. T. Staley \& G. M. Garrity. New York: Springer.

Wexler, H. M., Reeves, D., Summanen, P. H., Molitoris, E., McTeague, M., Duncan, J., Wilson, K. H. \& Finegold, S. M. (1996). Sutterella wadsworthensis gen. nov., sp. nov., bile-resistant microaerophilic Campylobacter gracilis-like clinical isolates. Int J Syst Bacteriol 46, 252-258.

Willems, A., Gilhaus, H., Beer, W., Mietke, H., Gelderblom, H. R., Burghardt, B., Voigt, W. \& Reissbrodt, R. (2002). Brackiella oedipodis gen. nov., sp. nov., Gram-negative, oxidase-positive rods that cause endocarditis of cotton-topped tamarin (Saguinus oedipus). Int J Syst Evol Microbiol 52, 179-186.

Xie, C. H. \& Yokota, A. (2004). Phylogenetic analyses of the nitrogenfixing genus Derxia. J Gen Appl Microbiol 50, 129-135. 